TURNER, I. M. 1990a. The seedling survivorship and growth of three Shorea species in a Malaysian tropical rain forest. Joumal of Tropical Ecology 6:469-478.

TURNER, I. M. 1990b. Tree seedling growth and survival in a Malaysian rain forest. Biotropica 22:146154.

ZAR, J. H. 1984. Biostatistical analysis. 2nd ed. Prentice-Hall Inc., Englewood Cliffs, NJ, USA.

Accepted 24 June 1993

\title{
ANNOUNCEMENT
}

\section{Ecology Institute Prizes 1994 in the field of Limnetic Ecology}

\section{Call for nominations}

Nominations are invited from all research ecologists and must reach the Chairperson of the ECI Jury before 30 September 1994.

Further information from:

Prof. Dr. O. Kinne (ECI Director)

Ecology Institute, Nordbünte 23, D-21385 Oldendorf/Luhe, Germany 